\title{
LANDSCAPE CHANGES AND FUNCTION LOST LANDSCAPE VALUES
}

\author{
SALlAY, Á.* - JOMBACH, S. - FILEPNÉ KovÁCS, K. \\ Corvinus University of Budapest, Dept. of Landscape Planning and Regional Development \\ 1118 Budapest, Villányi út 29-43., Hungary \\ (phone: +36-1-482-6281; fax: +36-1-482-6338) \\ *Corresponding author \\ e-mail: agnes.sallay@uni-corvinus.hu \\ (Received 24 $4^{\text {th }}$ October 2011; accepted $5^{\text {th }}$ December 2011)
}

\begin{abstract}
Land use and valuable landscape features are such kind of elements of the landscape, which are worth to be taken into account in a landscape plan that deals with the continuous sustainable transformation of landscapes, and provides frame for management, development and protection. The ratio of land use types and landscape features can be determined as landscape values that are relevant for management, protection, or planning purposes. The article focuses on land use driven landscape changes of the last few decades in general, and in a study area in Budapest Agglomeration called Southern Buda Region. It concentrates on changing landscapes represented by land use changes and remaining landscape values with lost functions in transformed or abandoned landscapes. The statistical documentation of land use types is relevant from the end of the $19^{\text {th }}$ century but surveying, inventarisation and protection of landscape values started at our department at the end of the 1970s. From that time it is obvious that the sprawling settlements endanger the existence of the valuable characteristic landscape elements of the past. This paper interprets such an analysis which concentrates on transforming character, altering landscape functions and the re-usability of landscape values of past landscapes in the pilot area.
\end{abstract}

Keywords: landscape, land use changes, landscape values, landscape elements, cellar, vineyard

\section{Introduction}

Landscape scenery, landscape character and all what people perceive as landscape depends partly on natural conditions like topography, geology, soil, climate, hydrography, natural habitats, and partly on human activities. The evidence and most basic remnants of human influence are land use types and distinct landscape features.

This paper focuses on land use, which is one of the most dominant scenic elements in the landscape. Its change determines the tendency of landscape transformations of human scale in the $20^{\text {th }}-21^{\text {st }}$ centuries. Sometimes the landscape elements of the former land use type can remain function lost, abandoned, in vain. But these can be regarded as values of the landscape representing the rural past of the former landscape. Even distinct patches of land use types of rural landscapes (pastures, vineyards, orchards) can become values in a suburban landscape.

European landscapes have been changing dynamically in the last few decades (Antrop, 2004; Feranec et al, 2010) and the management of landscape values can have enormous role in preserving, or in enhancing distinct landscape character. The sustained diversity of landscapes and the well interpreted character of landscapes can provide extra touristic income, support adequate land use. It can secure ecosystem processes and the preservation of habitats, specialise agriculture, food production and lift food industry, it can strengthen local identity of inhabitants and farmers, and these all mean further steps towards a sustainable future. 
The dominant changes of landscapes in Europe are driven by land use or land cover changes, coming from transformation of social, economic and ecologic attitudes towards landscape sites are:

- increase of built up land (Fischer et al., 2010; Antrop, 2004), e.g. sprawling settlements, industrial, logistical and commercial sites

- development of built linear infrastructure, e.g. highway, railway, energy and information transport

- appearance or increase of power plants (Möller, 2010; Frantál and Kunc, 2010), e.g. wind, water, atomic power, bioenergy plants

- increase of wasteland (waste dump sites, abandoned mines or agricultural sites)

- biomass energy plantation (Fischer et al., 2010), e.g. forest, crop, grass

- loss of pastures (Feranec et al., 2010), e.g. disappearance of grazing animals, increase of meadows

- decrease of land use types of rural landscape (Verburg et al., 2006; Hunziker, 1995), e.g. vineyards, orchards, gardens, arable land

- abandonment of built infrastructure elements of rural landscapes, e.g. wells, mills, cellars, granaries

- various impacts of climate change, e.g. disappearing glaciers, snow surface or aridity symptoms

- habitat rehabilitation sites, e.g. increase of semi-natural vegetation and wetlands

- transformation of touristic sites (Lasanta et al., 2007; Caletrío, 2010), e.g. adventure and wellness parks, ski resorts, mass and rural tourism

- increasing role suburban green, e.g. green belts and greenways, park forests in suburbs

- increasing social, economic and ecological function of city parks, e.g. multifunctional city parks.

Budapest Agglomeration has experienced most of the above mentioned landscape changes in the $20^{\text {th }}$ century, and this progress accelerated during the last decades (Schuchmann, 2008). The territory of Budapest Agglomeration was inhabited in the Roman era already. According to written records it was crossed by roads leading in direction of Szentendre, Aquincum, Csákvár and Tác which was used by the inhabitants up till the medieval ages. For a long time the main economic sector was agriculture but since the beginning of the $20^{\text {th }}$ century many inhabitants were commuting to work to the capital. "Prosperity" came in the second half of the $20^{\text {th }}$ century when during the industrialization after the World War II, people got work in the capital city. Many (especially the poorer ones) could not afford to buy a flat in Budapest and lived in the settlements next to the capital city in today's agglomeration. From that time the formerly agrarian villages with low population density continuously became towns and suburban settlements. This initiated the first significant wave of urbanization in the traditional rural region.

The second wave of population growth came in the 1980s when the people living in the capital started to move into the agglomeration to reach a better life quality and green environment. That time mostly white-collar families with small kids moved to the surrounding settlements to enjoy outstanding natural conditions in the vicinity of the capital city. This caused significant population growth in the area. The growth in number of inhabitants brought about the growth of the proportion of built up areas as 
well. The structure of settlements has become less dense, former agricultural areas or natural areas become built up land (Sallay and Kapovits, 2011).

Today the Budapest agglomeration (Fig. 1) is a concentration of urban areas around the core of Budapest creating an organic unit from the point of view of economy, infrastructure, labour market and services. 81 settlements belong to the agglomeration where 2457787 inhabitants, a quarter of the population of Hungary, lived in 2007. From this amount, 755290 lived out of Budapest.

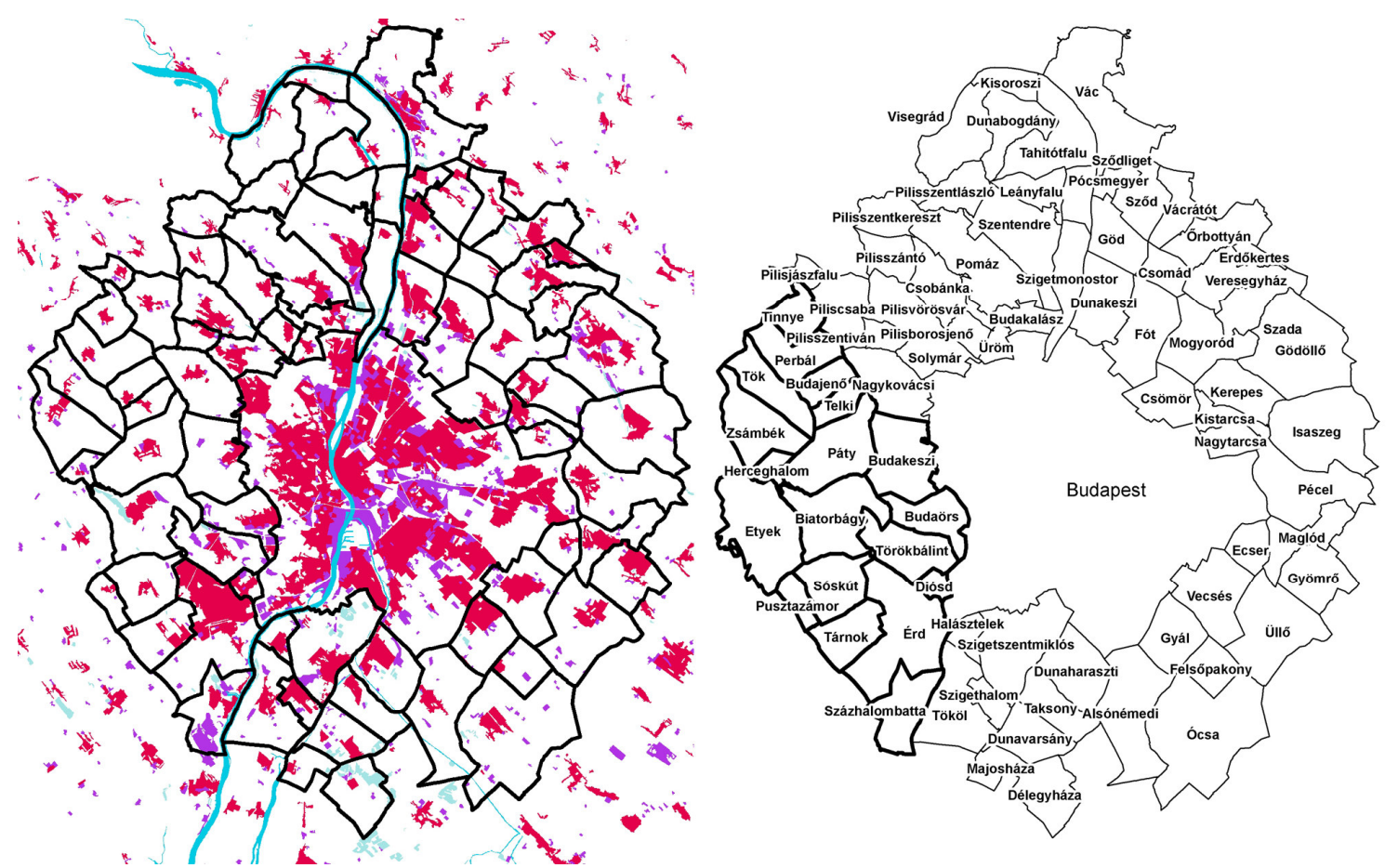

Figure 1. Budapest Agglomeration and the Southern Buda Region study area

\section{Materials and methods}

Of course all landscapes are continuously changing as the definitions and the general idea of European Landscape Convention highlights (Council of Europe, 2000). But many of them are transformed by enhancing or loosing characteristics. As the European Landscape Convention sentences in the $6^{\text {th }}$ article there is need for specific measures to manage landscapes. The countries besides raising awareness, training and education, need to:

- identify landscapes throughout the territory

- analyse landscape characteristics

- analyse the forces and pressures changing landscapes and their characteristics

- take note of changes

- assess the landscapes taking into account the particular values assigned to them by the interested parties and the population concerned.

Our research concentrates on the Southern Buda Region because of the rush transformation around the millennium. It focuses on these tendencies, characteristics, pressures and changes meanwhile it assesses landscape values. Southern Buda Region study area is the south-western "gate" of the Budapest Agglomeration (Fig. 1). Most of 
the above mentioned processes did or do appear in the area and continuously transform the character of the landscapes. The most dominant process is suburbanisation and decrease of rural landscape. The upcoming part of the article is dealing with the land use changes and landscape values of the Southern Buda Region.

The method of land use and landscape value analysis in the study area was complex. It was based on more components of different sources to explore the relevant characteristics of Southern Buda Region landscapes. The work started with literature overview and analysis of previous landscape value surveys, interpretation of historical maps and aerial photographs. Additionally it was extended with land use statistical data collection and analysis. After analysis of remote sensing and land cover data, the field survey of present landscape values with GPS and digital photographs started. The work ended with landscape value cadastering, validation and evaluation of results.

At the end landscape characterisation was done based on dominant land use types and related landscape features. As a result of character assessment the function analysis of landscape values was done. The function lost or function altered landscape values were defined and grouped. The future preferable use of these values could be defined and proposed, with regard on the new landscape functions of a suburbanised landscape (Fig. 2).

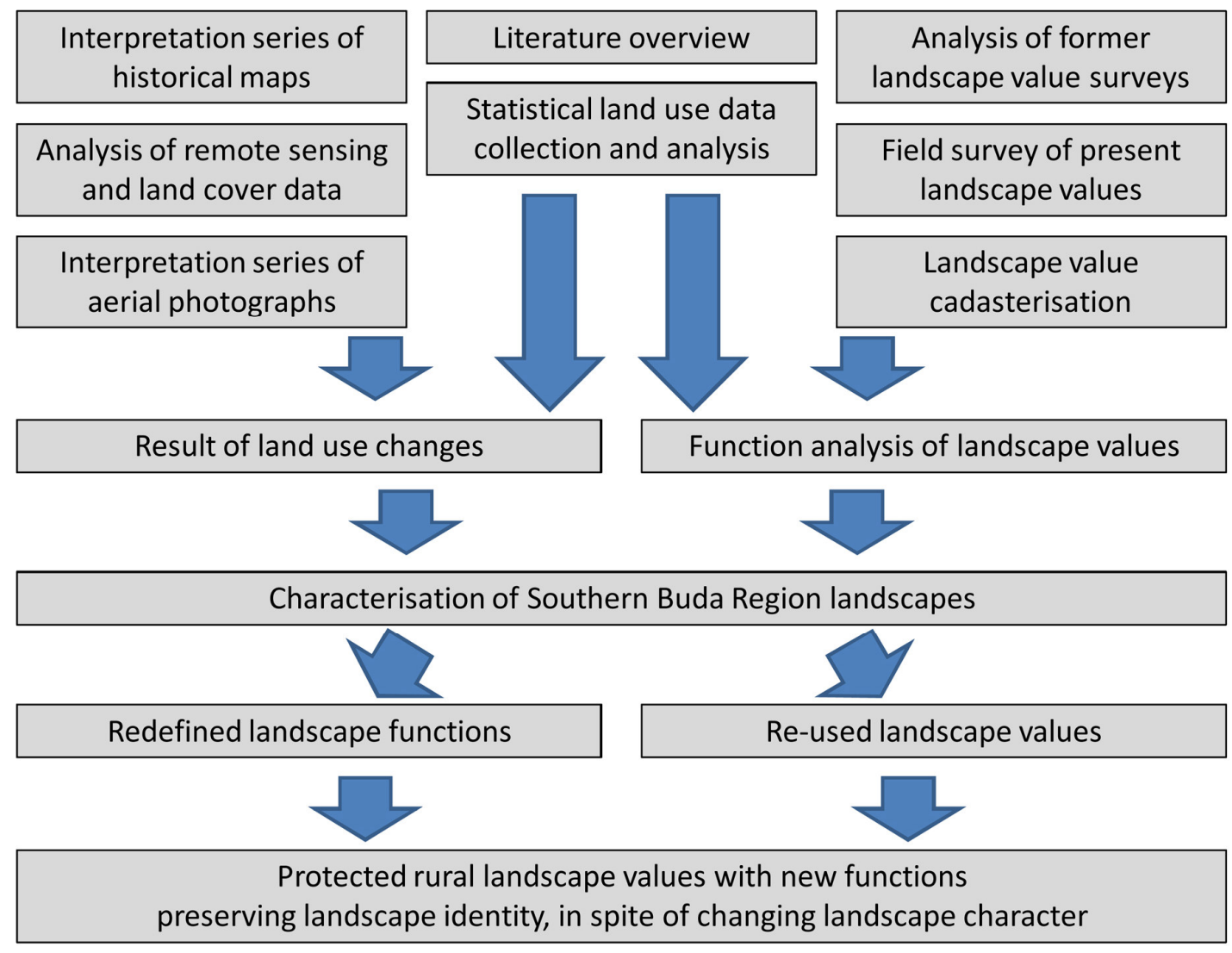

Figure 2. Research methods

The dominant transformation process in Southern Buda-Side is, that the built elements of the suburban landscape sprawl all over the region and take over the dominance in rural landscape continuously. The tendency of transformation (Fig. 3) is 
documented by historical maps from the $18^{\text {th }}$ century, aerial photographs from the $1940 \mathrm{~s}$ and satellite images from the 1980s up till today (Jombach and Sally, 2011).

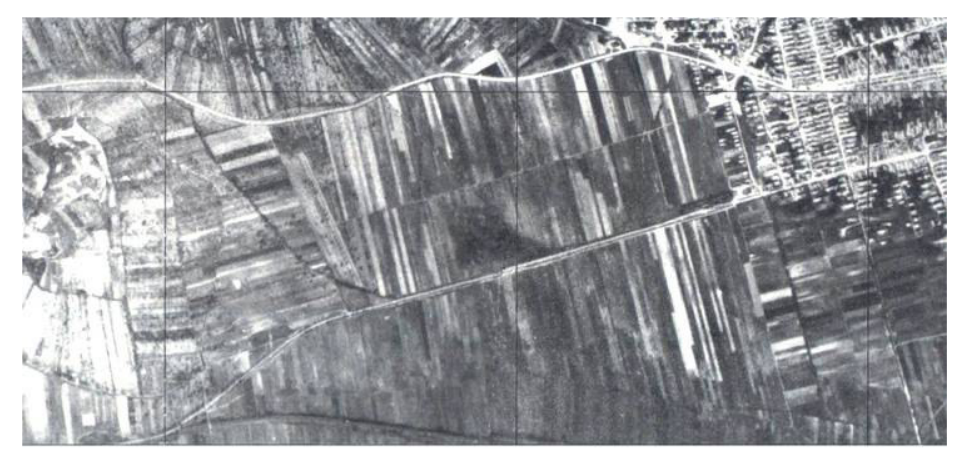

1940-ies $\left(^{*}\right)$

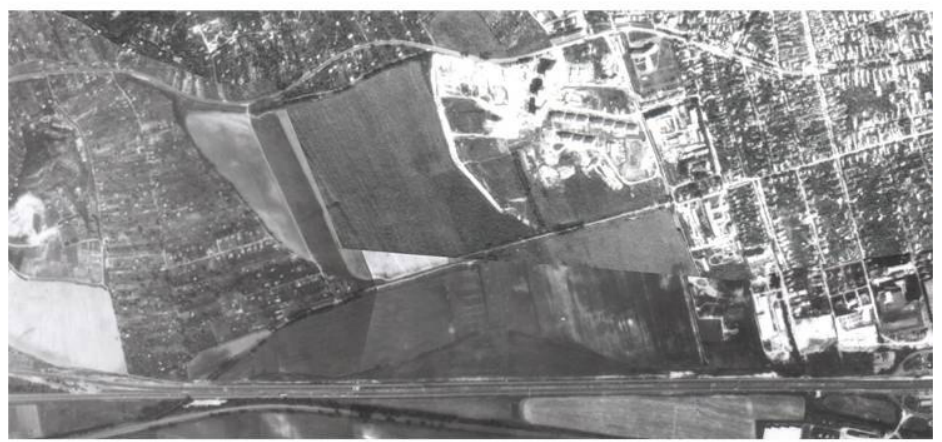

$1978-79\left({ }^{* *}\right)$

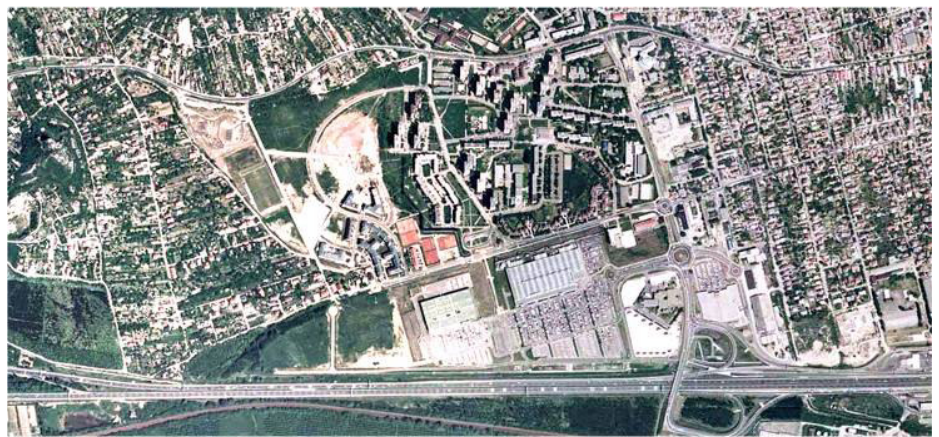

$2000\left({ }^{* *}\right)$

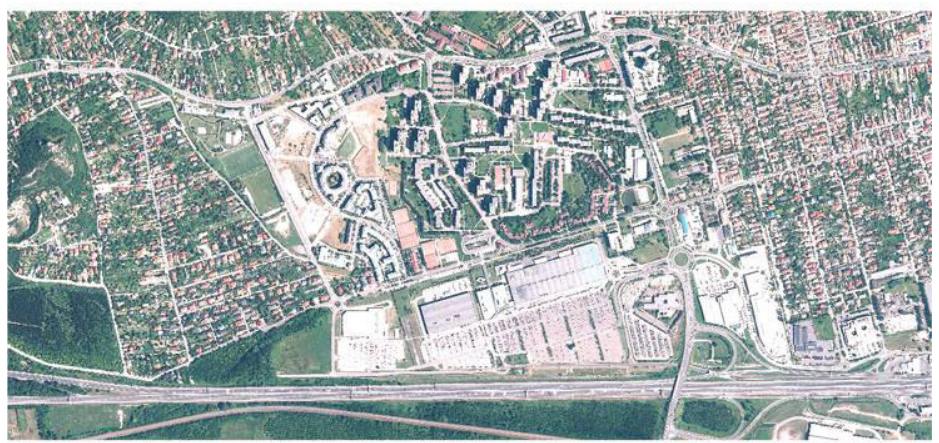

$\left.2010{ }^{* *}\right)$

Figure 3. Landscape change in Southern Buda Region study area at the edge of suburban and rural landscapes (source of aerial photographs and orthophotographs: *Military Museum, ** Institute of Geodesy, Cartography and Remote Sensing) 
Landscape value survey was managed in the frames of the Landscape Value Cadastre (TÉKA) research project in 2010 (Kollányi, 2009). More than 15000 landscape values of about 431 settlements were surveyed, uploaded and registered in the database (Fig. 4). As an average it means 35 values per settlement. The survey focused mostly on the area of Budapest Agglomeration the Danube-bend and the region along river Ipel. Further surveys are related to other pilot regions or other projects as the survey of landscape values is fundamental part of landscape assessment and planning projects (Kollányi and Csemez, 2011; Sallay and Jombach, 2011).

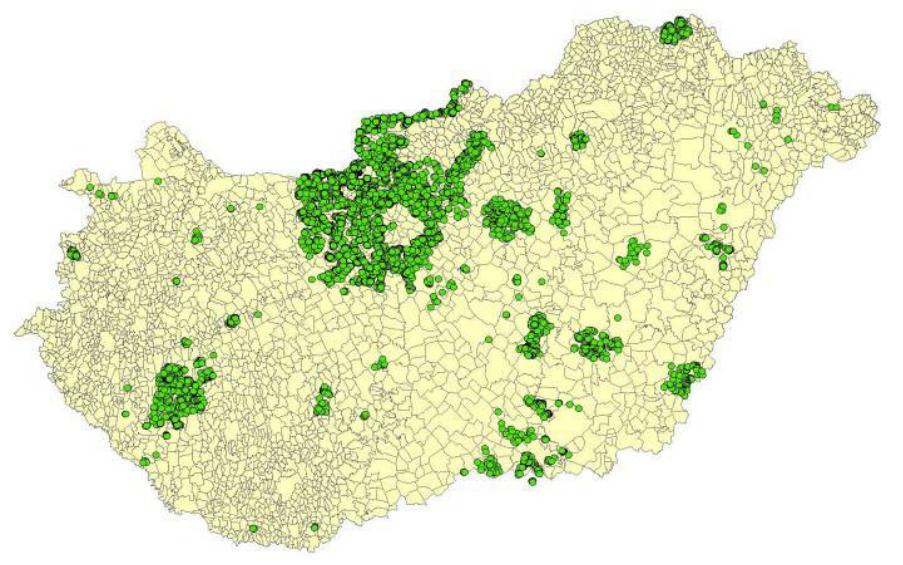

Figure 4. Landscape values surveyed in the TÉKA project (2010)

The surveyors have registered more than 5000 (5138) landscape values in the agglomeration and more than 1200 in the Southern Buda Region. The landscape values were grouped according to the standard (MSZ 20381): cultural-historical (red), landscape scenery (blue) natural (green). Fig. 5 shows the distribution of the particular categories.
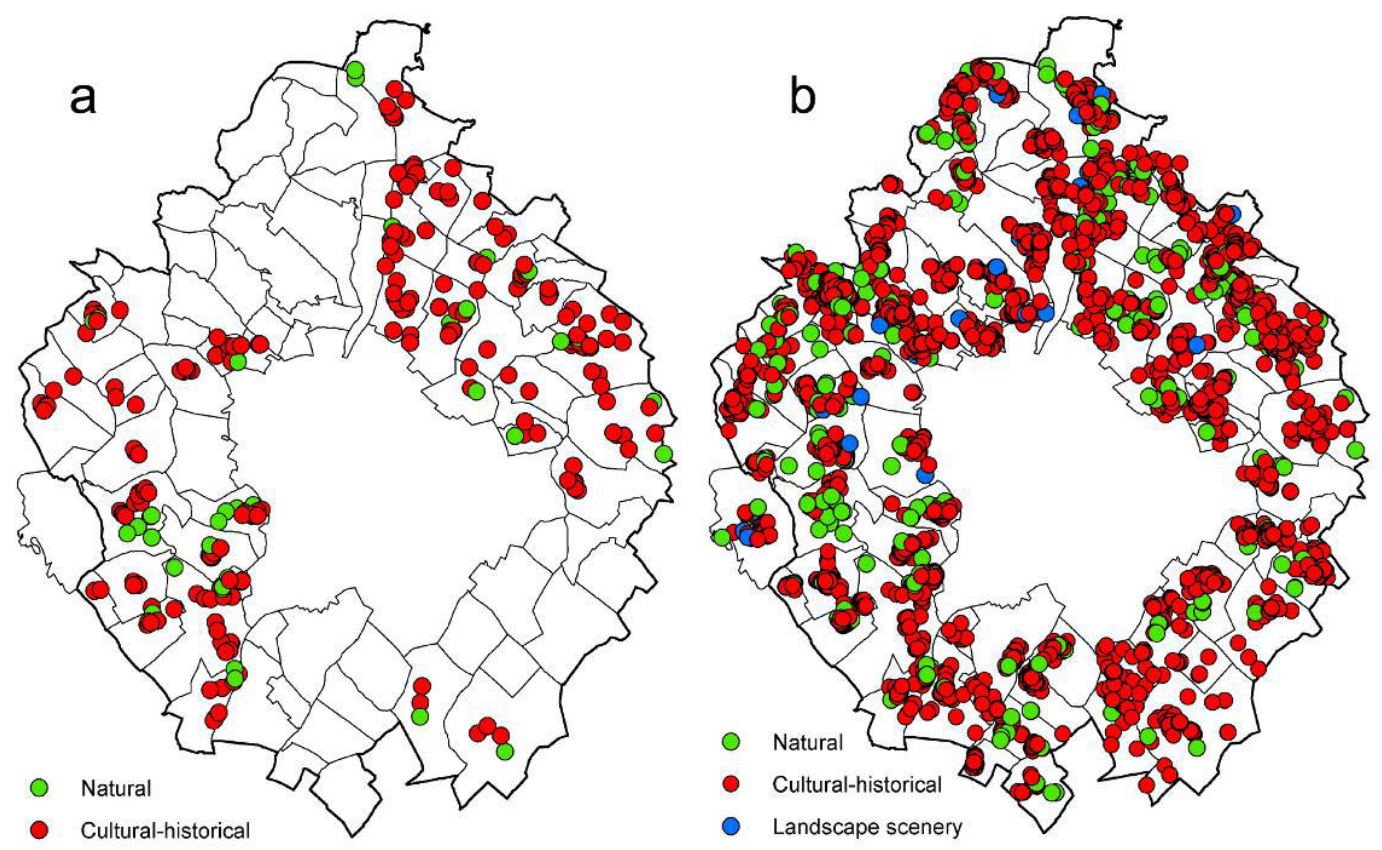

Figure 5. a) Natural and cultural-historical values of Budapest Agglomeration in the 1970s b) Distribution of landscape values in 2010 
According to Fig. 5, most of the values are of cultural-historical character. The hardest definable values proved to be the values of landscape scenery (Sallay, 2011). Our surveyors indicated that it is difficult to determine what kind of landscape feature is representing actually the value of landscape scenery and in many cases they have not designated landscape scenery values because of the poor accessibility of lookout points.

Parallel to the surveys we processed the results of former projects of landscape value survey as well. The most complete project of this type was carried out in 1979, which registered the "significant environmental values" of several counties. In the frames of the TÉKA project we uploaded all data concerning Pest County. In the present area of the agglomeration during the survey of 1979, 110 values were registered from which 97 are cultural values, 13 natural values according to the present categories (Pestterv, 1979).

If we compare the two periods we can see different distribution of the points: the survey in 2009 covered all settlements while in the 1970 just the settlements which were important from the point of view of tourism or other aspects. In the '70s the natural values appeared less important in the survey as the public has not recognized its significance that time.

\section{Results}

We experienced dramatic changes in the land use ratio of the Southern Buda Region during the analyzed period 1895-2010 (Fig. 6). Besides that the share of non-cultivated built up areas has grown from $4 \%$ to $32 \%$ the formerly dominant arable land (66\%) is reduced greatly (to $37 \%$ ). The relatively low ratio of meadows and pastures has shrunk to half and it is far below the country average. This fact already highlights that pastures provide unique landscape scenery and can be regarded as landscape values that sustain a special kind of "land use" like horse riding in this region. Forests are growing mostly according to the tendency perceived in the whole country, thus we can consider that the share of forests has grown gradually making up $18 \%$ of the area corresponding to the national average.

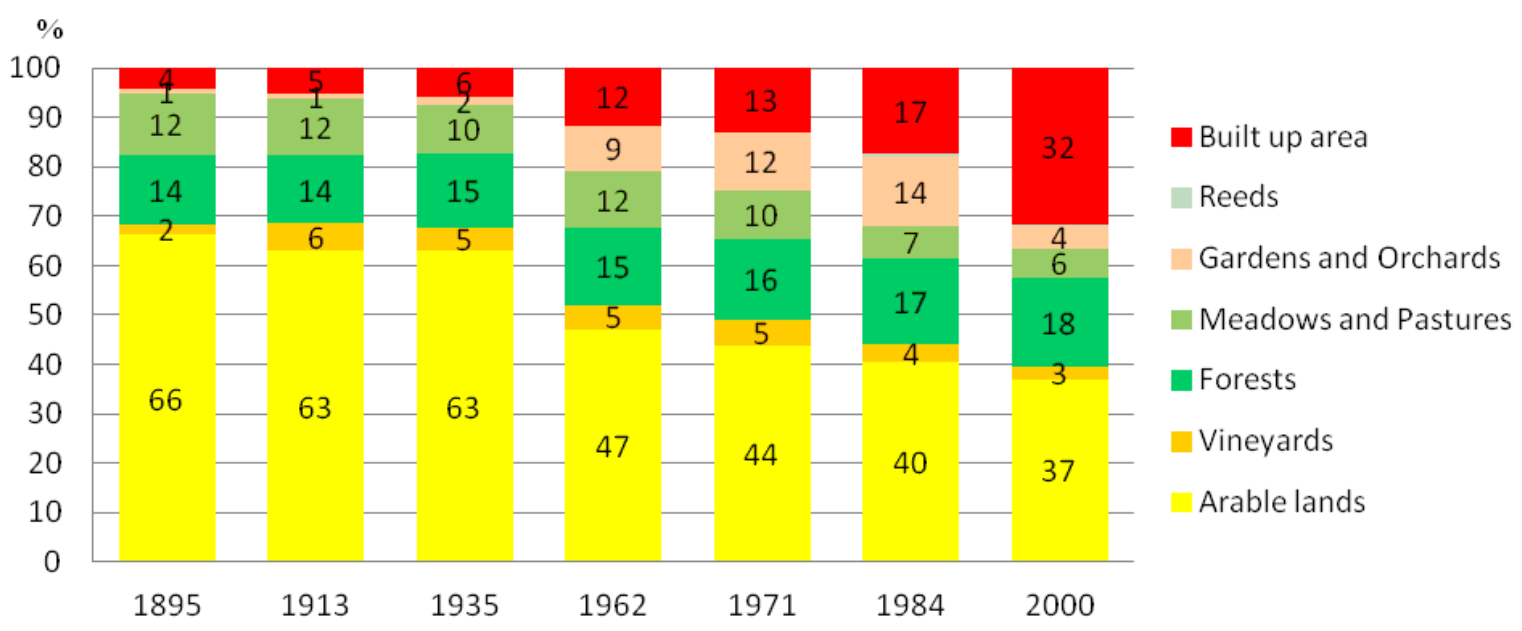

Figure 6. Land use changes in the Southern Buda Region in the $20^{\text {th }}$ century (source: KSH (http://ksh.hu) and TakarNet (http://takarnet.hu)) 
The sprawl of built up land is part of a very significant landscape character changing process today as the remote sensing and land cover data overview proved and as the land use statistical data analysis proves the process started already in the beginning of the $20^{\text {th }}$ century but the rush sprawl happened in the last 30-40 years (Fig. 7). It is clearly visible that the process strengthened the most in the last decade. Today in case of many settlements built up land reaches the $40 \%$ and in one case exceeds the $90 \%$ (Diósd).

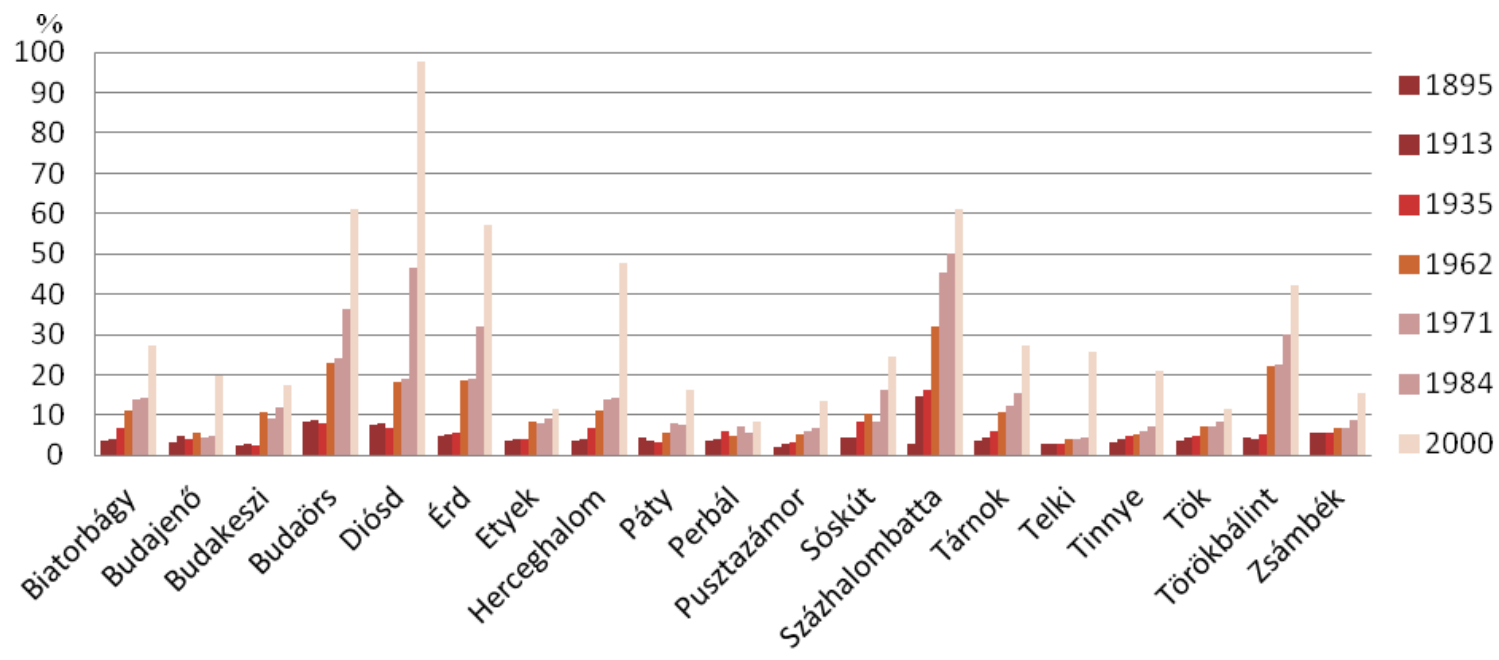

Figure 7. Changes of built up area in Southern Buda Region (source: KSH (http://ksh.hu) and TakarNet (http://takarnet.hu)

The dataset shows that in spite of the public opinion and literature overview the orchards and gardens flourished not at the beginning of the $19^{\text {th }}$ century, but only during $1970-80$ s with a share of $12-14 \%$ in the land use ratio, and nowadays we have again only a few percent of this land use type in the territory.

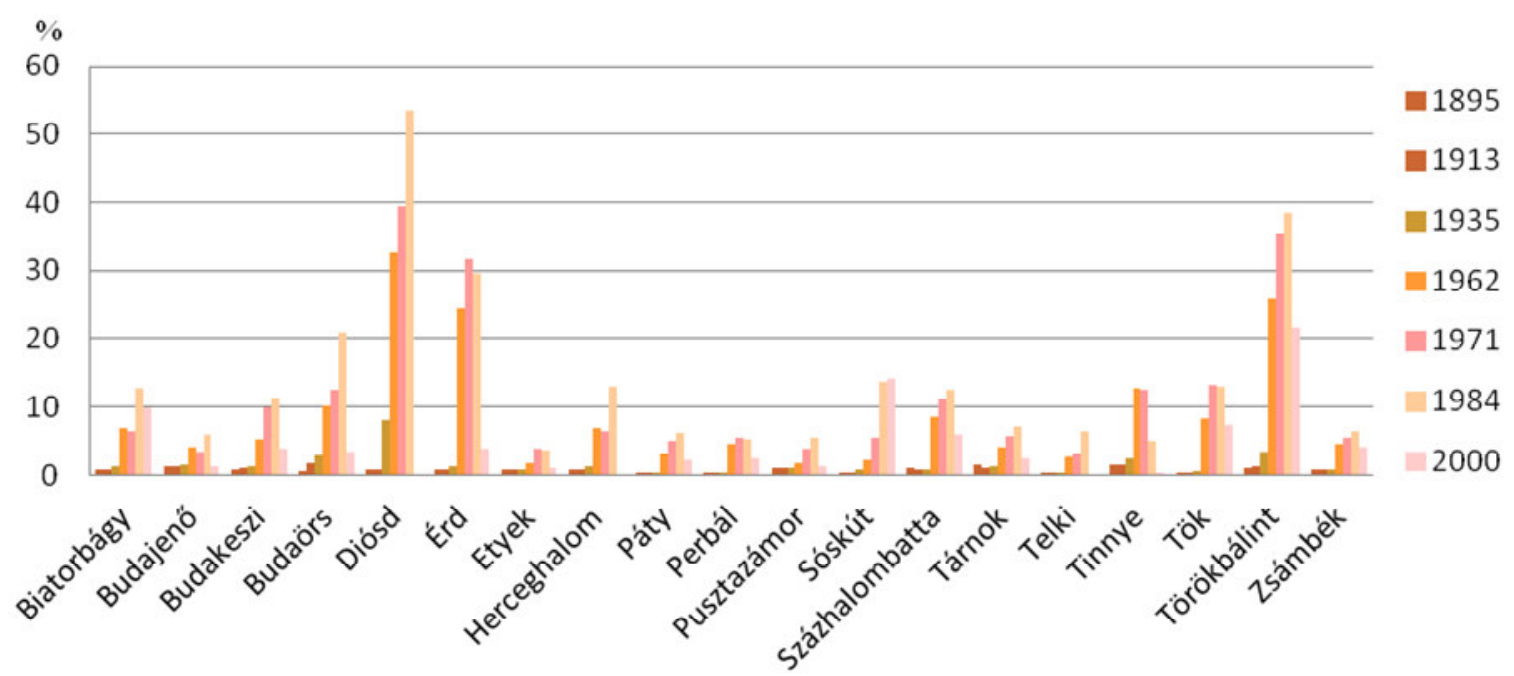

Figure 8. Changes of gardens and orchards in Southern Buda Region (source: KSH (http://ksh.hu) and TakarNet (http://takarnet.hu))

In case of settlements Diósd, Érd, Törökbálint and Budaörs the map and aerial photograph overview proved that the big ratio of gardens and orchards provided the 
development potential in direction of residential kind of built up land use. These four settlements had the largest ratio of gardens and orchards in the region, more than $20 \%$ in 1984, and this land use provided the breakaway option to residential development. Thanks to this history we can find a lot of fruit trees might be regarded as landscape values in newly developed residential parts of these settlements (Fig. 9).

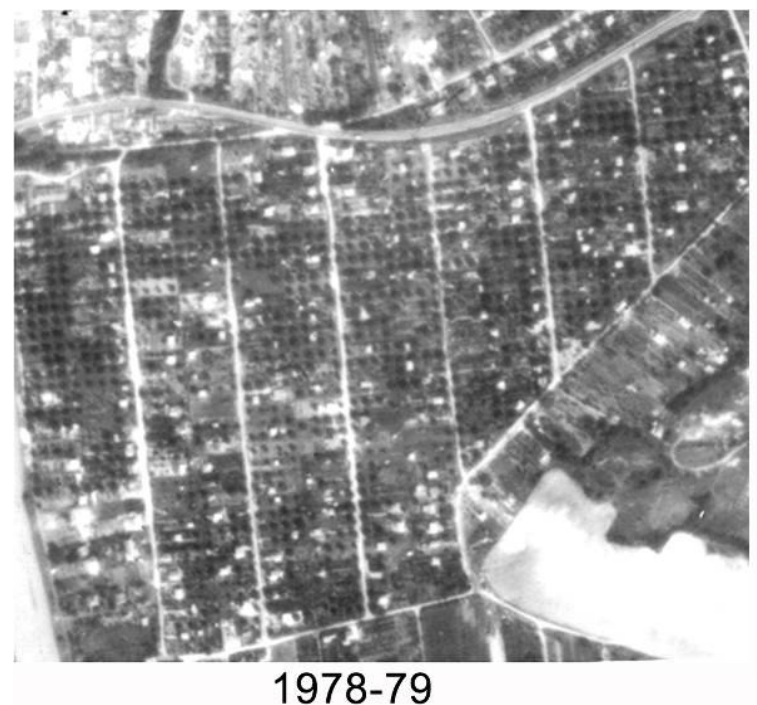

Figure 9. Orchard-residential area transformation in Budaörs Cartography and Remote Sensing)

The literature overview already showed that viticulture is a traditional activity in the region since ages, and in spite of the vine pest in the second half of the $19^{\text {th }}$ century, vineyard was all the time a characteristic land use type of the region (Filipszky, 2000). Especially in the middle and the early second half of the $20^{\text {th }}$ century the Southern Buda Region was significantly planted with vineyards (Fig. 10). This and the decline of this land use from the 1980s were proved by the interpretation of aerial photograph series from the 1940s to 2010, as well as the growth of the built up land partly here too.

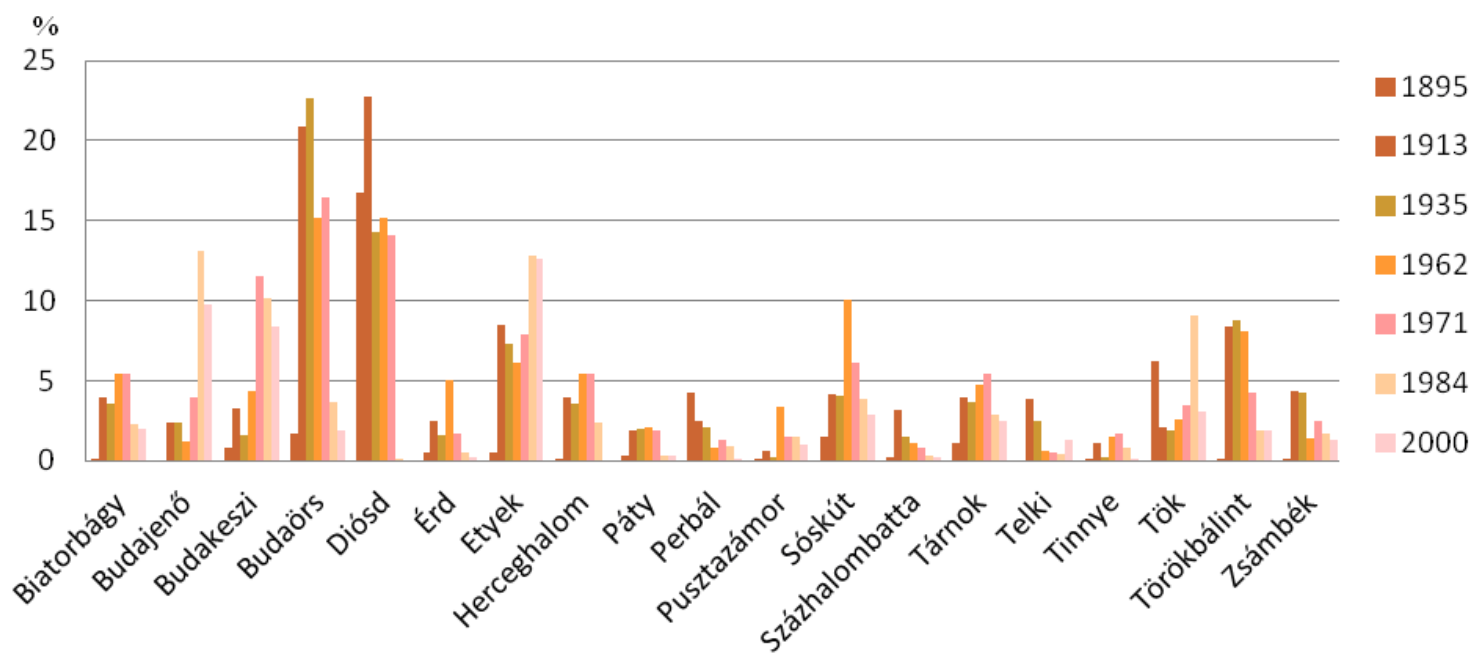

Figure 10. Change of vineyards in the settlements of Southern Buda Region (source: KSH (http://ksh.hu) and TakarNet (http://takarnet.hu)) 
The vineyards of small parcels almost disappeared from the most developed towns or settlements of the region (Budaörs, Diósd, Érd). Even in villages like Zsámbék, Tök, Budajenö, Etyek do have low ratio of small parcelled vineyards, and the tendency is that large parcels of vineyards become dominant and they can support the competitive vine production. According to the data of 1895 the vineyards covered small areas, because the first available data show already the conditions after the vine pest (phylloxera) when the traditional viticulture was shrunk. The most significant vineyards remained in Diósd after the vine pest but for now the vineyards disappeared without leaving a trace just the wine cellars give evidence of the formerly flourishing viticulture. From the point of view of viticulture Perbál was significant and we can still find a few vineyards nowadays, but the ratio of built up areas has grown dramatically. New vineyards were established only in Etyek which is related to the relatively new identity of the settlement: there is hardly any traditional landscape value connected to viticulture and the majority of cellars were built in the last decades. The expansion and popularity of viticulture in Etyek is marked by the statues related to viticulture raised by the selfgovernment.

The results of the landscape value survey reflect that in the South-Western sector of the agglomeration there are only a few settlements where viticulture has not been significant. The survey shows that there are no cellars registered as landscape values in the settlements where the vineyard land use ratio was less then $1 \%$. We find cellars in the greatest number in those settlements where viticulture was really significant and dominant land use form in the beginning and the middle of the $20^{\text {th }}$ century (Fig. 11).

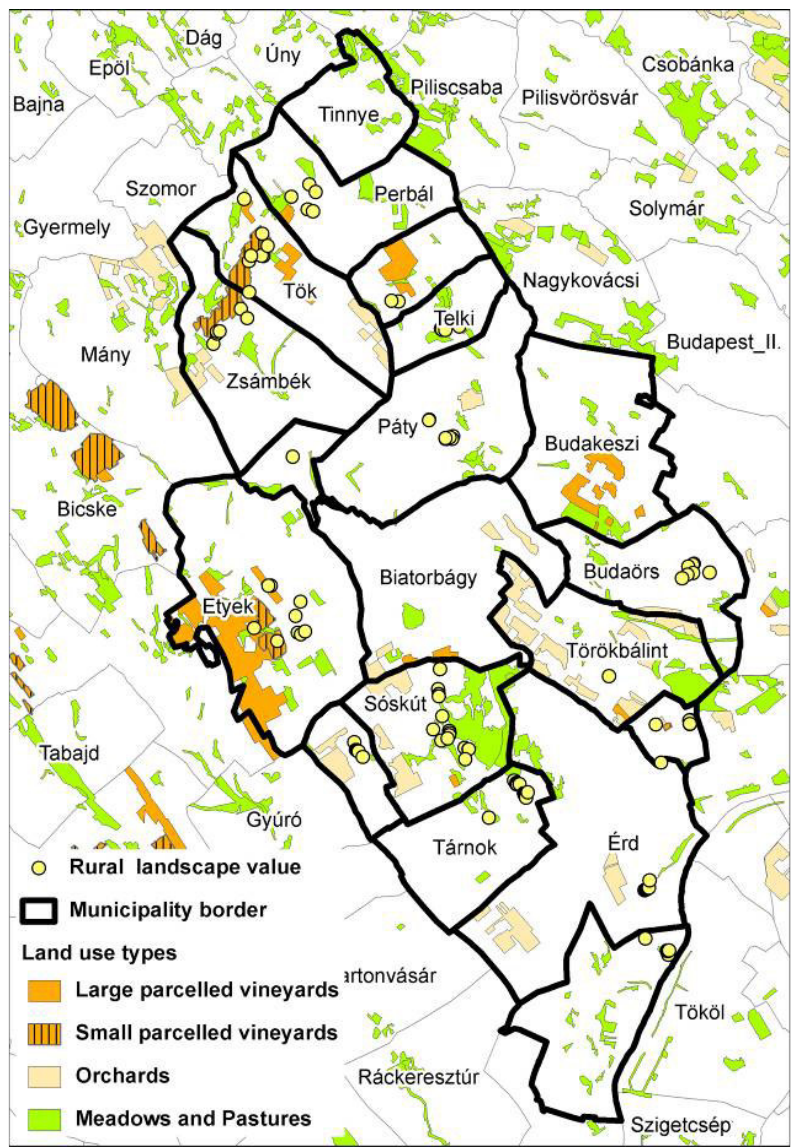

Figure 11. Landscape values related to agriculture in 2010 and certain rural land use types in 2000 based on CLC50 (data source: Institute of Geodesy, Cartography and Remote Sensing) 
These settlements are: Diósd, Perbál, Tök and Budaörs. Even then, there are all around nice wine cellars in the region of different state and use, like the cellar hill in Páty, the row of cellars in Budajenő or Tárnok, and Sóskút.

Comparing the two landscape value surveys we see that during the " 70 s several agrarian buildings have lost its function and begun to decay (Fig. 12). Buildings without function disappeared by now, so regrettably these cannot be included in the register of 2010. These are definite symptoms of the continuous shrink of rural landscape in this region.
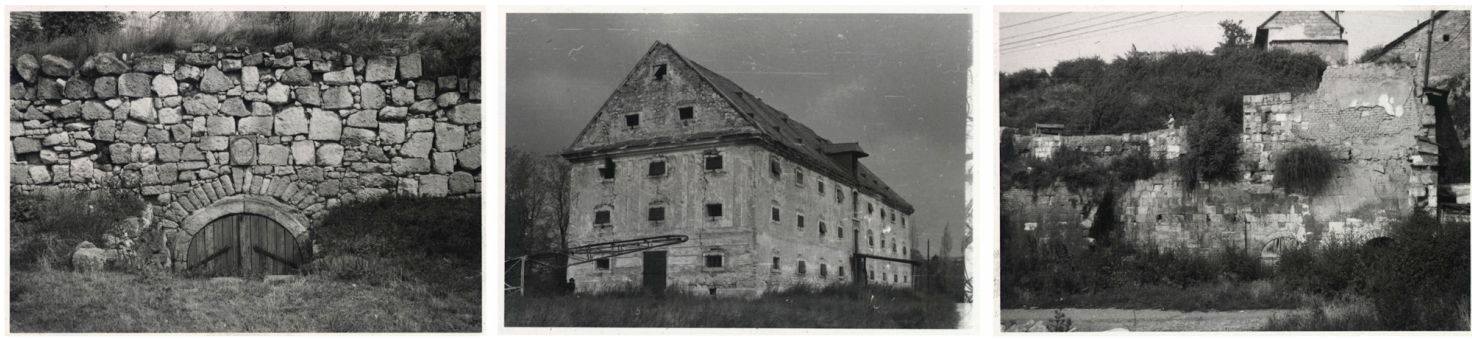

Figure 12. Cellar in Diósd in 1975, granary in Sóskút in 1979, cellar in poor condition in Budaörs, 1980 (source: TÉKA, http://tajertektar.hu)

The agricultural buildings, which were re-used even if the related land use has disappeared, became significant values of the settlements included in both landscape value surveys (1970 and 2010). These values are mostly cellars (Fig. 13). In many cases the buildings were preserved by getting new functions: converted to family house, cottage or catering (Fig. 14). In case the agricultural buildings were neither for the owner nor for the settlement valuable then these are already in trouble, abandoned or disappeared. Sometimes these get into poor conditions and homeless do move in that accelerates the decaying process of neighbouring values.
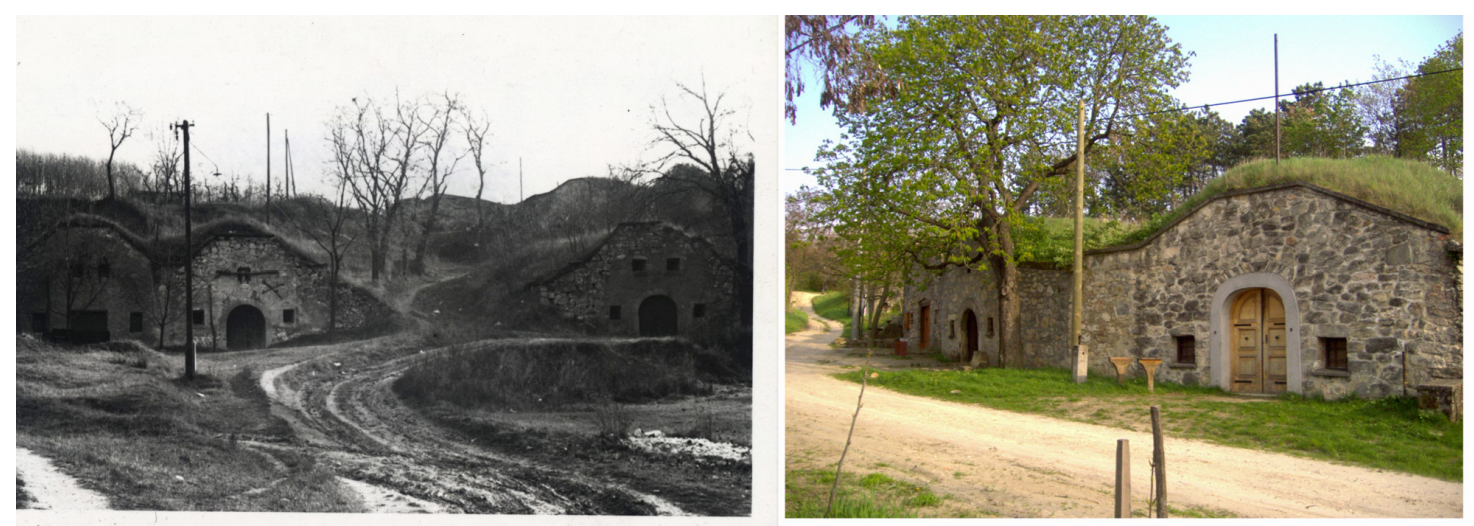

Figure 13. Cellars of Páty in the 1970s and in 2010 (source: TÉKA, http://tajertektar.hu) 

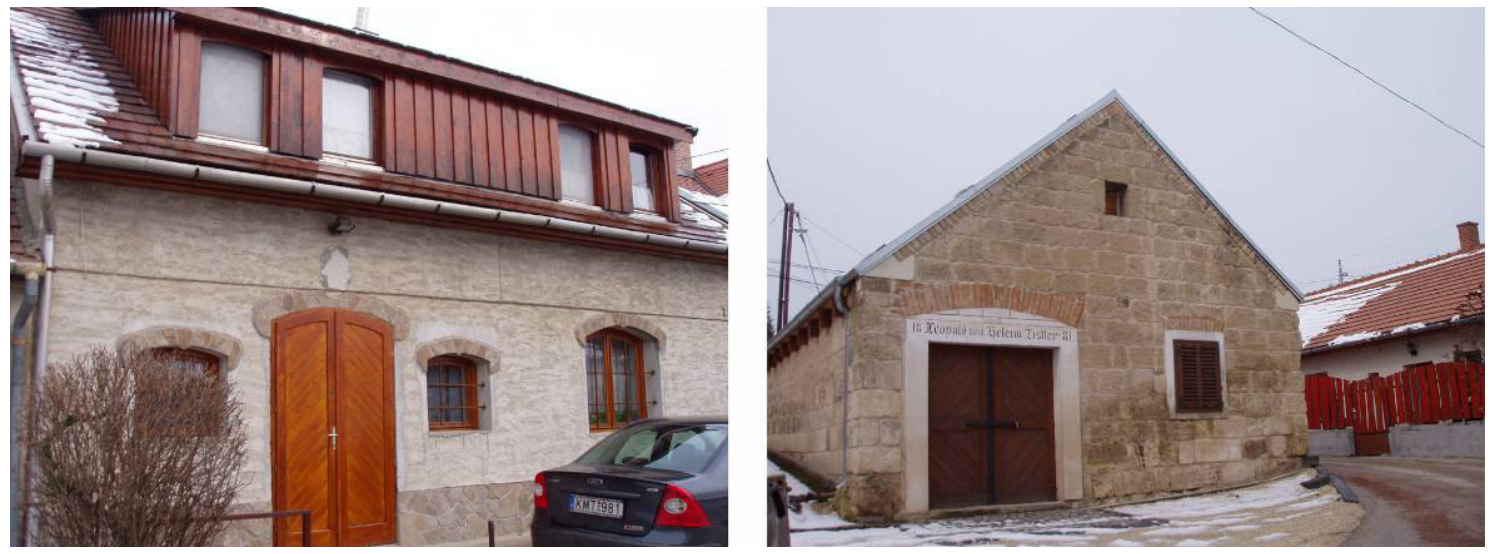

Figure 14. Former cellar transformed to dwelling house in Diósd, and cellar in Diósd from 1881 (source: TÉKA, http://tajertektar.hu)
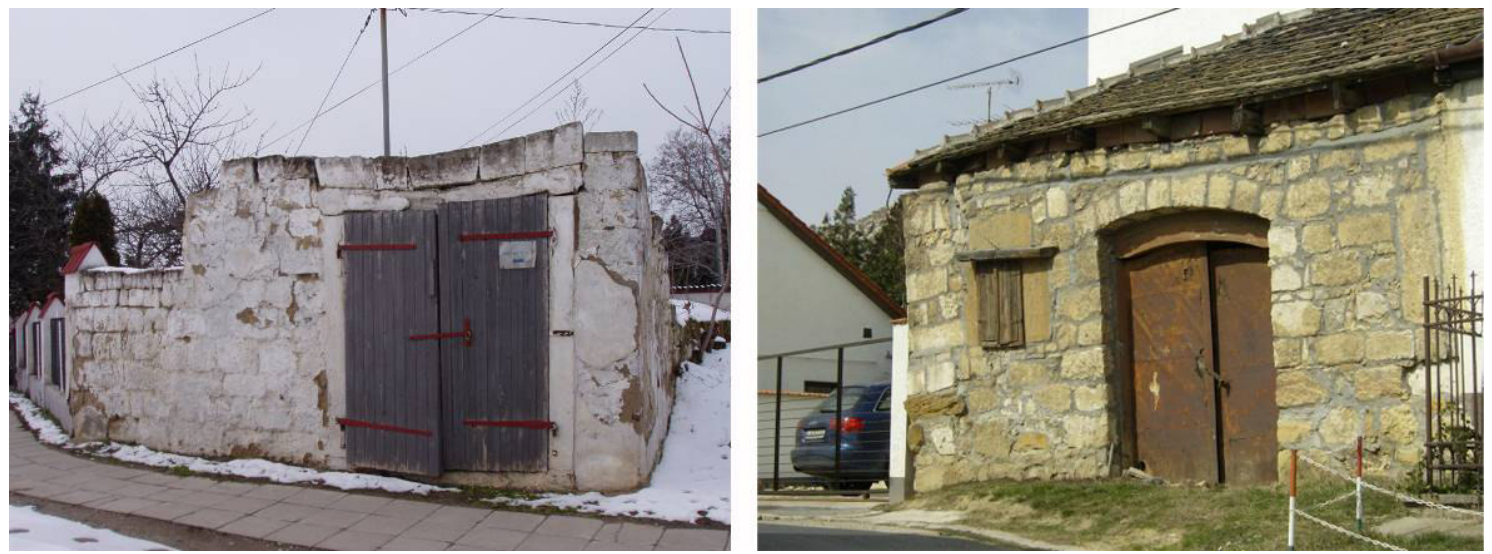

Figure 15. Disused cellar in Diósd, and cellar in Budaörs (source: TÉKA, http://tajertektar.hu)

Cellars are built in settlements where viticulture gained significance in the last decades such as Etyek, which is one of the active members among the settlements of the former wine region of Etyek-Buda. The newly built cellars are potential landscape values. In these settlements the master plans have a great role in regulation of construction in order to preserve the existing landscape character (Fig. 16 and 17).
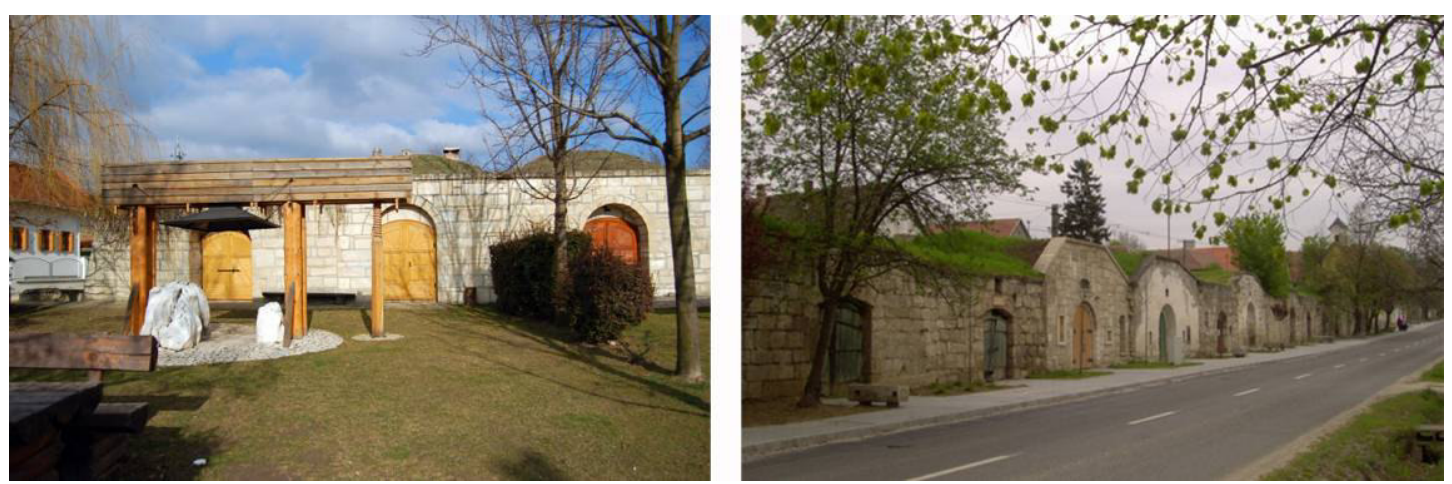

Figure 16. Modern cellars in Etyek and old cellars in Budajenö (source: TÉKA, http://tajertektar.hu) 


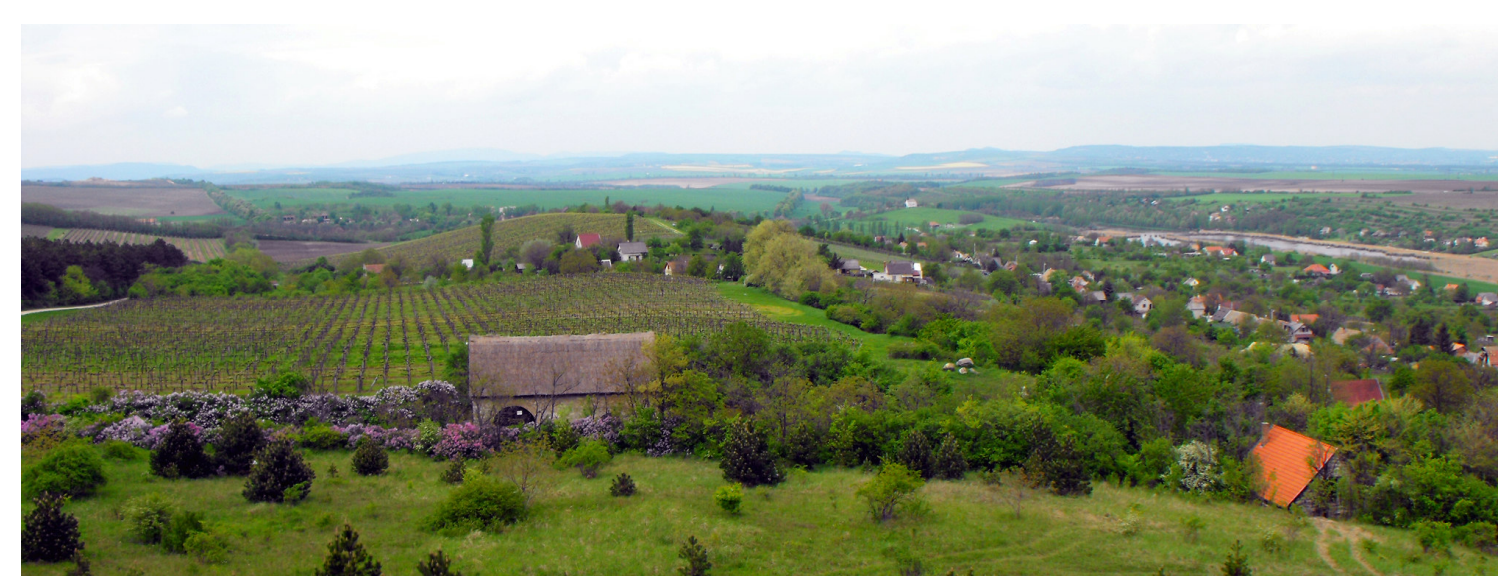

Figure 17. Old press house next to large parcelled vineyards in Etyek

\section{Discussion}

The perceived landscape changes usually can be represented with exact landscape elements, land use types, landscape values. In case of Southern Buda Region we can say that the landscape function has altered as well in last few decades. The rural landscape of the 1970s represented by vineyards, orchards, arable lands and others has partly disappeared and the suburban landscape of built up land with increasing urban woods appeared (Table 1). Some landscape elements of the former landscape functions continuously lose their functions like cellars in the suburbs without vineyards. These remnants of the former rural landscapes can be considered as values in the stakeholders mind and can be re-used and vitalized with the original function or with a new function.

Table 1. Summary of dominant changes in landscape elements in Southern Buda Region

\begin{tabular}{c|c}
\hline $\begin{array}{c}\text { Rural landscape elements disappearing in the } \\
\mathbf{2}^{\text {nd }} \text { part of the } \mathbf{2 0} \text { th } \\
\text { century }\end{array}$ & $\begin{array}{c}\text { Suburban elements sprawling in the } \\
\mathbf{2}^{\text {nd }} \text { part of the } \mathbf{2 0}^{\text {th }} \text { century }\end{array}$ \\
\hline Arable lands, pastures, vineyards, orchards & $\begin{array}{c}\text { Roads and highways, various residential areas, } \\
\text { Commercial, store or logistic areas, Forests and } \\
\text { urban woods }\end{array}$ \\
$\begin{array}{c}\text { Artificial landscape elements related to rural life } \\
\text { and agriculture (wells, bridges, granaries, dirt } \\
\text { roads, cellars, grazing domestic animals etc.) }\end{array}$ & $\begin{array}{c}\text { Artificial landscape elements related to urban / } \\
\text { suburban landscapes (petrol stations, parking lots, } \\
\text { noise barriers, billboards, fences, traffic lights, etc) }\end{array}$ \\
\hline
\end{tabular}

The protection of landscape values can result a good solution for a monument but the revitalization of the landscape element would mean the internal use in the society's life. This case the rehabilitation of built landscape elements with restrictions and valuespecified regulations could result the sustainable maintenance. Re-use of a landscape value can be various. A specimen or a well in a pasture land, a granary at the side of an arable land, or a mill on the hillside can become a revitalized landscape value, representing the past or the present rural use of land and to visualize the presence of working human hands in the landscape. In a suburban landscape such sceneries can seem very ancient like, native, and unique, that strengthens the historical identity of the landscape. The potential use of wine cellars in a suburban landscape can be one of the followings: 
- the original function: cellar for small parcelled vineyards

- the original function: large parcelled vineyards in cooperation with cellars

- commercial building, store, souvenir shop

- tourist information office

- venue of various events (village gatherings, forums)

- base of residential development

- Local History Collection

- protected monument status with any of the essential functions mentioned above.

\section{Conclusions}

As the statistic data and the historic maps show the share of land use forms has changed dramatically in the region during the last century however in different ways in the settlements. Basically the shrunk of arable land and the increase of built up areas is dominant all around the region. If we look at the data of the different land use forms we see the following progresses and results:

- The share of cultivated areas has decreased first gradually than dramatically since the beginning of the $20^{\text {th }}$ century in the South-Western part of Budapest Agglomeration.

- The areas taken out of cultivation (especially by development of residential areas) were formed in the areas of former gardens and orchards, vineyards, plough fields.

- The viticulture was withdrawn by the end of the $20^{\text {th }}$ century in all settlement except Etyek. Generally the area of former small parcelled vineyards transformed mostly to residential areas.

- The share of gardens and orchards which has been significant land use form during the $19^{\text {th }}$ century, have shrunk drastically giving place for residential areas. In all settlements we have witnessed a drastic expansion of residential areas especially in Diósd of which administrative area became almost totally built up area in the last decades.

- In the case of land use changes of great scale the landscape values as cellars, granaries etc. preserve the memory and traces of the traditions of Southern Buda Region.

These changes of land use forms have resulted in the transformation of rural landscape to suburban sites changing the landscape character drastically. As the landscape structure and land use have changed the function of former (mostly) agricultural buildings have changed as well. Those buildings are preserved which got new functions: the former farm buildings are mostly used as cottages, family homes, local museums, restaurants etc. Unfortunately the buildings which have lost their functions are in decay:

- the state of disused farm buildings is deteriorating, regardless of property relations

- the granaries serving several settlements in the past remained without functions.

We have found one good example: the granary in Budajenő got just new function - a tourist centre will be installed in the building. 
As final conclusion we can state that because of the drastic changes of the land use forms, the landscape character transformed from a rural landscape into a suburban landscape. The traces of the former landscape character are preserved just by the surviving landscape values. We consider it important to retain and enhance local identity by preserving, reusing these architectural values. We promote the intention of local communities to give new functions to the deteriorating but unique landscape values. The remained farm buildings with new functions can enhance the identity of local population and give new identity for the settlers in spite of the changed landscape character.

Acknowledgements. The research was co-financed by TÁMOP-4.2.1/B-09/1/KMR-2010-0005 project. We thank Rita Várszegi for fulfilling the formal requirements.

\section{REFERENCES}

[1] Antrop, M. (2004): Landscape change and the urbanization process in Europe. Landscape and Urban Planning 67: 9-26.

[2] Caletrío, J. (2010): Tourism, landscape change and critical thresholds. - Annals of Tourism Research 38(1): 313-316.

[3] Council of Europe (2000): European Landscape Convention. - European Treaty Series, ETS No. 176, Florence, Italy

[4] Feranec, J., Jaffrain, G., Soukup, T., Hazeu, G. (2010): Determining changes and flows in European landscapes 1990-2000 using CORINE land cover data. - Applied Geography 30: $19-35$.

[5] Filipszky I. (2000): Elfeledett évszázadok (Forgotten centuries). - Budaörs Város Önkormányzata, Budaörs

[6] Fischer G., Prieler, S., van Velthuizen, H., Berndes, G., Faaij, A., Londo, M., de Wit, M. (2010): Biofuel production potentials in Europe: Sustainable use of cultivated land and pastures, Part II: Land use scenarios. - Biomass and Bioenergy 34: 173-187.

[7] Frantál, B., Kunc, J. (2010): Wind turbines in turism landscapes Czech Experience. Annals of Tourism Research 38(2): 499-519.

[8] Hunziker M. (1995): The spontaneous reafforestation in abandoned agricultural lands: perception and aesthetic assessment by locals and tourists. - Landscape and Urban Planning 31: 399-410.

[9] Jombach, S. Sallay Á. (2011): Remote sensing and GIS in Landscape Character Assessment. - Problems of Landscape Ecology 30 (in press)

[10] Kollányi L. (2009): Tájértékek kataszterezésének metodikája. - In: LOV Tudományos Ülésszak összefoglalói, p. 68-69., BCE Tájépítészeti Kar

[11] Kollányi L., Csemez A. (2011): Táji értékek, egyedi tájértékek egy egységes rendszerben. - In: Sallay, Á. (ed) Tájértékek szerepe a tájkarakter meghatározásában (elsősorban a budapesti agglomeráció példáján), BCE Tájtervezési és Területfejlesztési Tanszék, Budapest

[12] Lasanta, T., Laguna, M., Vicente-Serrano, S. M. (2007): Do tourism-based ski resorts contribute to the homogeneous development of the Mediterranean mountains? A case study in the Central Spanish Pyrenees. - Tourism Management 28: 1326-1339.

[13] Möller, B. (2010): Spatial analyses of emerging and fading wind energy landscapes in Denmark. - Land Use Policy 27: 233-241.

[14] MSZ 20381 (2010): Az egyedi tájértékek kataszterezéséről

[15] Pestterv (1979): Pest megye jelentős környezeti értékei. - Kutatási jelentés, Pest megyei Tanácsi Tervező Vállalat, Budapest 
[16] Sallay Á (2011): Tájértékek a budapesti agglomerációban. - In: Sallay, Á. (ed) Tájértékek szerepe a tájkarakter meghatározásában (elsősorban a budapesti agglomeráció példáján), BCE Tájtervezési és Területfejlesztési Tanszék, Budapest

[17] Sallay Á., Jombach, S. (2011): Changing landscape values. - Problems of Landscape Ecology 30 (in press)

[18] Sallay, Á., Kapovits, J. (2011): Zöldút-tervezés mint a turizmusfejlesztés eszköze (Tájépítész és civil együttmüködés a Zsámbéki-medencében). - In: Michalkó, G. Rátz, T. (eds) A turizmus dimenziói: humánum, ökonómikum, politikum., Kodolányi J. Főiskola, Székesfehérvár

[19] Schuchmann, P. (2008): A zöldövezet fejlesztés lehetőségei a Budapest agglomerációban. - Falu Város Régió 1: 7-13.

[20] Verburg, P.H., Schulp, C.J.E., Witte, N., Veldkamp A. (2006): Downscaling of land use change scenarios to assess the dynamics of European landscapes - Agriculture, Ecosystems and Environment 114: 39-56. 